ks. Piotr Briks

\title{
Apokaliptyka jako próba „ucieczki do przodu”
}

Artykuł ten wypadałoby zacząć od podania definicji apokaliptyki. Problem w tym, że nikt jeszcze takiej definicji nie wymyślił. Podjęto oczywiście mnóstwo prób, ale żadna z nich nie zakończyła się sukcesem ${ }^{1}$. W tej sytuacji najlepszym rozwiązaniem wydaje się po prostu syntetyczny opis elementów pojawiających się najczęściej w pismach nazywanych apokaliptycznymi. Nie jest to rozwiązanie idealne, ale dla naszych potrzeb wystarczające ${ }^{2}$.

Po pierwsze, utwory apokaliptyczne są z reguły pseudoepigraficzne. Znaczy to tyle, że autentyczny autor podszywa się pod jakąś postać z przeszłości cieszącą się szczególną estymą (jak np. Henoch, Abraham, Lewi, Daniel itp.). Zabieg taki nadaje tekstowi, a tym samym nauce, którą przekazuje, autorytet jego „autora”. Głównym bohaterom historii apokaliptycznych bardzo często towarzyszą aniołowie, którzy objaśniają znaczenie znaków lub wizji (Gabriel, Uriel, często też aniołowie bez imienia). Tacy interpretatorzy podkreślają objawiony, czyli ostatecznie boski, charakter czytanej czy słuchanej wyroczni.

Po drugie, pisma te pełne są obrazów i symboli, snów i fantastycznych wizji, przenikania się świata ludzi, aniołów i demonów, wreszcie zapowiedzi i wizji przerażających, katastroficznych lub przeciwnie - cudownych, majestatycznych wydarzeń.

Po trzecie, w apokalipsach bardzo często pojawiają się pełniące różne role zwierzęta - począwszy od znanych nauce gatunków, poprzez różnego rodzaju mutanty i mieszańce, a skończywszy na smokach i przerażających bestiach. Stwory te pełnią co najmniej dwojaką funkcję: symbolizują pewne postacie, grupy ludzi, czy całe królestwa, równocześnie potęgują nastrój tajemniczości, niesamowitości czy grozy.

${ }^{1}$ Por. G. von RAD, Teologia ST, Warszawa 1986, 597. Także sama terminologia związana z apokaliptyką jest tematem burzliwych dyskusji - więcej na ten temat: P. D. HANsON, HBMI 465-488.

${ }^{2}$ Dla tych, którzy chcieliby pogłębić swoje wiadomości na temat apokaliptyki, jej historii, terminologii i tematyki (w szczególności w ST) polecam przede wszystkim (pominąwszy artykuły słownikowe): H. H. Rowley, Apokalyptik, Köln 1966; P. Grelot, SM I 225-231; J. Michl, SM I 214-223; W. R. Murdock, History and Revelation in Jewish Apocalypticism, Interpr 21/1967, 167- 
Po czwarte, typowym elementem dla apokalipsy są liczby. Autorzy z lubością odwołują się do ich mniej lub bardziej powszechnie rozumianych znaczeń, a niekiedy nadają im, dla spotęgowania efektu, tylko sobie wiadome znaczenie. Dokładnie to samo odnosi się do różnego rodzaju okresów czasu.

Wreszcie sam styl apokaliptyczny ${ }^{3}$ charakteryzuje się tajemniczością, niedopowiedzeniami, monumentalizmem, atmosfera grozy lub tryumfalizmu. Tyle jeśli chodzi o środki formalne.

\section{Nauka apokaliptyków}

Tak jak wielorakie są środki literackie używane w literaturze apokaliptycznej, tak samo niezwykle różnorodna jest jej tematyka. Chociaż dla

187; F. Dingermann, Die Botschaft von Vergehen dieser Welt und von den Geheimnissen der Ewigkeit. Beginnende Apokaliptik im AT, [w:] Wort und Botschaft, Würzburg 1967, 329-342; W. J. P. BoYD, Apocalyptic and Life after Death, StEv 5 (1968), 39-56 (TU 103); B. HeMELSOET, BL 83-84; P. von DER OSTEN-SACKEN, Die Apokalyptik in ihrem Verhältnis zur Prophetie und Weisheit, München 1969; J. M. Sснмidt, Die jüdische Apokalyptik. Die Geschichte ihrer Erforschung von den Anfängen bis zu den Textfunden von Qumran, Neukirchen 1969; J. ScHREINER, Alttestamentliche-jüdische Apokalyptik. Eine Einführung, München 1969; P. D. HANsON, Jewish Apocalyptic Against Its Near East Environment, RB 78 (1971), 31-58; L. STACHOWIAK, Apokaliptyka i eschatologia u progu ery chrześcijańskiej, AK 7 (1971), 57-68; P. D. HAnson, The Dawn of Apocalyptic. The Historical and Sociological Roots of Jewish Apocalyptic Eschatology, Philadelphia 1979; K. KосH, Ratlos vor der Apokalyptik, Gütersloh 1970; D. RochaIs, Les origines de l'apocalyptique, ScE 25 (1973),15-50; H. GESE, Anfang und Ende der Apokalyptik dargestell am Sacharjabuch, ZThK 70 (1973), 20-49; W. R. Millar, Isaiah 24-27 and the Origin of Apocalyptic, Missoula 1976; J. J. Collins, The Jewish Apocalypses, Semeia 14 (1979), 21-59; J. CARMignac. Qu'est que l'apocalyptique? Son emploi à Qumran, RQ 10 (1979-1980), 333 (bogata bibliografia tematu na s. 3-6); C. MünCHOw, Ethik und Eschatologie. Ein Beitrag zum Verständnis der frühjüdischen Apokalyptik, Stuttgart 1981; K. MüLLER, Studien zur frühjüdischen Apokaliptik, Stuttgart 1991; S. JĘDRZEJEWSKI, Apokaliptyka jako rodzaj literacki, RBL1 (1998), 29-35; W. SzlachetKa, Przyszłość świata w świetle Biblii, Studia Gdańskie 12 (1999), 139-151.

${ }^{3}$ G. von Rad protestuje przeciw określaniu apokaliptyki jako ,gatunku”: ,z punktu widzenia historii form stanowi coś w rodzaju mixtum compositum, które, gdy chodzi o historię tradycji, pozwala wnioskować o bardzo złożonej prahistorii” (Teologia ST, Warszawa 1986, s. 608, przypis 28). Innym problemem jest szeroko dyskutowana kwestia teologicznych, religijnych czy społecznych korzeni tego zjawiska literackiego. Począwszy od K. Kocha zaczęto rozróżniać pomiędzy apokaliptyką jako ruchem a powstałym w jego łonie gatunkiem czy choćby stylem literackim. Zwolennikami traktowania apokaliptyki przede wszystkim jako szczególnej formy literackiej są m.in.: C. Rowland, The Open Heaven. A Study of Apocalyptic in Judaism and Christianity, New York 1982; H. Stegemann, [w:] D. Hellholm (ed.), Apocalypticism in the Mediterranean World and the Near East, Tübingen 1983, 495-530). Apokaliptykę bardziej jako nurt teologiczny niż jedynie formę literacką postrzega np. E. P. SANDERs, [w:] D. Hellholm (ed.), Apocalypticism in the Mediterranean World and the Near East, Tübingen 1983, 447-459. Całość dzieła D. Hellholma zawiera zbiór bardzo różnych opinii na temat sposobów pojmowania zjawiska apokaliptyki.

Dyskusję nad pytaniem, czy apokaliptyka jest jedynie zjawiskiem literackim, obszernie przedstawił D. Sim (Jewish and christian Apocalipticism in the ancient world. Problems and Prospects, [w:] Religion in the Ancient World. New Themes and Approaches, Amsterdam 1996, 491-504). 
wprawnego badacza literatury apokaliptycznej odróżnienie jej szaty literackiej od przesłania dzieła jest czymś absolutnie oczywistym, wciąż jeszcze bardzo wielu czytelników dzieł apokaliptycznych zatrzymuje się na warstwie zewnętrznej i traktuje ją jako meritum przekazu. Fakt, że wszystkie tego typu teksty wydają się opisywać przyszłość, świadczy jedynie o przyjętej w tej literaturze konwencji literackiej. Tak jak powieść historyczna umieszcza swoich bohaterów w mniej lub bardziej historycznej przeszłości, bajki dzieją się „za górami, za lasami” i koniecznie „dawno, dawno temu”, tak samo czas akcji apokalips nie ma wiele wspólnego z ich merytoryczną tematyką i przesłaniem. Najbardziej czytelnym przykładem tego zjawiska może być spisana w II w. Księga Daniela, która po to, aby swoje nauczanie dotyczące wydarzeń aktualnych umieścić w przyszłości, słowa przepowiedni wkłada w usta męża Bożego z okresu dawno już minionej niewoli babilońskiej.

Przynajmniej w odniesieniu do kanonicznej literatury apokaliptycznej, można zaryzykować stwierdzenie, że ma ona charakter przede wszystkim pedagogiczny. Po pierwsze starała się, poprzez ukazanie całościowej perspektywy, uciszyć niepokój wywołany np. obecnymi wydarzeniami, czy niezrozumiałą dla Hebrajczyków opieszałością JHWH. Po drugie miała kształtować ducha - dodawać nadziei, uzbrajać w cierpliwość, umacniać w wierze i zaufaniu do Boga. Wreszcie jej kolejnym zadaniem było ostrzeżenie współczesnych jej czytelników przed zgubnymi konsekwencjami ich grzesznego postępowania, a przez to nakłonić ich do zmiany sposobu życia. Albo, z drugiej strony, obiecując cudowną interwencję Mesjasza (jakkolwiek by interpretować tę postać), rozbudzić lub wzmocnić nadzieję, na szczęśliwe zakończenie nieszczęśliwej teraźniejszości.

Biblijną literaturę apokaliptyczną można by porównać do wielkiej lupy, która pozwala w dużym powiększeniu oglądać niezauważalne gołym okiem rzeczy, ale równocześnie należy pamiętać, że powiększenie to na obrzeżach niesamowicie wręcz zniekształca obraz.

Ulubionym motywem pism apokaliptycznych jest ostateczna walka dobra i zła, sił światła i ciemności, prawdy i kłamstwa. W kluczu dualizmu przedstawiana jest także historia - czas obecny poddany jest panowaniu zła, a najbliższa przyszłość panowanie to tylko umocni. Zło będzie się nasilać aż nadejdzie moment ostatecznej konfrontacji z Bogiem. Wtedy wszystko ulegnie radykalnej przemianie. Dualizm apokaliptyczny jest dodatkowo „czarno-biały”: zło jest złem bezwzględnym, a dobro - dobrem doskonałym. Brak jest jakichkolwiek światłocieni. Potwierdza to konstatację, że zadaniem tej literatury nie miał być opis rzeczywistości, ale jasne i jednoznaczne ustalenie standardów życia. 
Moim zdaniem apokaliptycy nie mają wspólnej wizji przyszłości. Prawdą jest, że dość powszechnie przypisuje się im fatalizm oraz pesymizm. Fatalizm odnosiłby się do oceny możliwości wpływania pojedynczego człowieka na swój własny los oraz na losy własnego kraju czy świata. Pesymizm z kolei dotyczyłby wiary w szanse na pozytywne zmiany w najbliższej przyszłości. Należy jednak zauważyć, że obydwie hipotezy pozostają zasadne jedynie przy założeniu, że apokalipsy de facto opisują spodziewaną przyszłość. Jak już napisałem wcześniej, założenie takie wydaje się nieuzasadnione. Apokalipsy czytane w kluczu pedagogicznym muszą być optymistyczne, gdyż inaczej byłyby sprzeczne same w sobie. Nie ma sensu wychowywać kogoś, jeśli nie wierzy się ani w skuteczność tego procesu, ani nawet w ogóle w jego sensowność.

Koniecznie należy jednak zauważyć, że większość apokaliptyków nie wychowuje pojedynczego człowieka. Nie jest to pedagogika indywidualna, ale kolektywna. Pociagga to za sobą istotne konsekwencje. Pierwszą z nich jest właściwe rozłożenie akcentów pedagogicznych. Podstawowym celem biblijnych pism apokaliptycznych wydaje się być kształtowanie postawy Hebrajczyków, a dopiero w drugim rzędzie ich postępowania. Kolejność taka uwarunkowana jest okolicznościami, w jakich powstawały te teksty.

\section{Geneza apokaliptyki}

Większość badaczy przyjmuje, że apokaliptyka zrodziła się w II w. przed Chr., w schyłkowym okresie profetyzmu izraelskiego, jako jego mutacja albo odpowiedź na pytania, na które ani profetyzm ${ }^{4}$, ani literatura sapiencjalna ${ }^{5}$ nie znalazły odpowiedzi. Tłem jej powstania miały być prześladowania za czasów Antiocha IV Epifanesa oraz zawirowania dziejowe następnych dziesięcioleci. Wydaje się to jednak ujęciem nadmiernie zawężonym ${ }^{6}$. Początków apokaliptyki należałoby szukać także poza Izraelem, a w nim samym także nieco wcześniej, co najmniej w okresie niewoli babilońskiej’. Faktem natomiast jest,

${ }^{4}$ B. Vawter, Apocalyptic Its Relation to Prophecy, CBQ 22 (1960), 33-46.

${ }_{5}^{5}$ Por. D. Michel, Weisheit und Apokaliptik, [w:] A. S. van Der Woude (ed.), The Book of Daniel in the Light of New Findings, BEThL 106, Leuven 1993, 413-434.

${ }^{6} \mathrm{Na}$ szersze tło apokaliptyki, a także jej pozaizraelskie korzenie wskazuje G. vON RAD (Teologia ST, Warszawa 1986, 602-608). Za późnym okresem datowania początków literatury apokaliptycznej opowiada się J. J. CoLlins, Apokaliptyka i eschatologia ST, KKPŚ 889.

${ }^{7}$ Pewne rysy stylu apokaliptycznego można dostrzec już u proroków przedwygnaniowych. Fragment: „Słońce zmieni się w ciemność, a księżyc w krew, gdy przyjdzie dzień Pański, dzień wielki i straszny" $(\mathrm{Jl} 3,4)$ jest takiego stylu klasycznym przykładem. Atmosfera apokaliptyki wyraźnie widoczna jest również u wygnaniowego proroka Ezechiela (na szczególną uwagę zasługują tu rozdziały 1, 38 i 39). Patrz również: P. SACCHI, L'apocalittica giudaica e la sua storia, Brescia 1990, 132; S. JĘDRZEJEwski, Apokaliptyka jako rodzaj literacki, RBL 1 (1998), 31; P. Clifford, Krótka historia końca czasów, Warszawa 1999, 42n. 
że okres prześladowań za czasów Antiocha IV, późniejsze niepokoje, a przede wszystkim kryzys w dotychczasowych formach uprawiania teologii, spowodowały szczególnie żywy rozkwit tego nurtu ${ }^{8}$, którego szczytowy okres przypada na czasy międzytestamentalne. Teksty apokaliptyczne w Piśmie Świętym ST to przede wszystkim Iz 24-27; Jl 3-4; Ez 30; 37; 40-48; Za 9-14 i praktycznie cała Księga Daniela. Szczególnie bogata w motywy apokaliptyczne jest literatura apokryficzna $^{9}$ oraz piśmiennictwo qumrańskie ${ }^{10}$.

\section{Ucieczka do przodu}

Pisma profetyczne szczególnie te z okresu perskiego i greckiego (czyli mniej więcej VI-III w. przed Chr.) coraz częściej odsuwały wizję poprawy losu, nagrody dla sprawiedliwych, pomsty na wrogach, spełnienia się obietnic tzw. mesjańskich (i znowu, jakkolwiek by je rozumieć) na czas coraz bardziej odległy. Najlepszym tego przykładem jest III część Księgi Izajasza, II część Księgi Ezechiela czy Księga Daniela. Prorocy jakby tracili nadzieję, że realizacja ich zapowiedzi może nastąpić już niedługo. Tę „niewiarę” wydają się coraz bardziej rekompensować przerysowaniami w wizjach wspaniałej przyszłości, albo w grozie zapowiadanych kar. Wydaje się, że to właśnie stanowiło, obok wpływów pozaizraelskich, jeden z najistotniejszych faktorów powstania nurtu apokaliptycznego w literaturze hebrajskiej. Powoli obietnice zbawienia - czyli wybawienia z obecnego nieszczęścia - stawały się coraz bardziej niesamowite i coraz bardziej odległe w czasie. Literatura apokaliptyczna nie skupia się na losie indywidualnego człowieka. Jej wizje dotyczą losów całych ludów, krain, całego świata, a nawet kosmosu. Człowiek bywa w niej najczęściej jedynie swego rodzaju statystą, bardzo często zupełnie biernym adresatem łaski, czasami nawet niezależnej od jego indywidualnego postępowania. Przeważnie wystarczyło nie wykluczyć się samemu ze wspólnoty Izraela. Podstawowym przesłaniem biblijnych pism apokaliptycznych wydaje się apel o przetrwanie obecnego czasu w wierności JHWH. Siłę tego apelu potęgują przerysowania ewentualnych konsekwencji obserwowanych wydarzeń.

${ }^{8}$ Dyskusję nad uwarunkowaniami rozkwitu apokaliptyki w II w. przed Chr. przedstawił wyczerpująco L. STACHOWIAK (Apokaliptyka i eschatologia u progu ery chrześcijanskiej, AK 7 (1971), 57-68).

${ }^{9}$ Należy wymienić tu przede wszystkim: 1 i 2 Księga Henocha, 4 Księga Ezdrasza, 2 i 3 Księga Barucha, Apokalipsa Abrahama, Księga Czuwających, Wyrocznie Sybilli 3; Wniebowstąpienie Mojżesza oraz Testament XII Patriarchów. Nie jest to oczywiście pełna lista, ale pozycje wskazywane jako dla rozwoju apokaliptyki najistotniejesze (por. także: K. KocH, The Rediscovery of Apocalyptic, Naperville 1972, 23).

${ }^{10} \mathrm{~Np}$. Reguła Wojny, peszery do Habakuka i Nahuma. Patrz: P. R. DAviEs, Eschatology at Qumran, JBL 104 (1985), 39-55; I. FRÜHLING, Pesher. Apocalyptical Literature and Qumran, [w:] The Madrid Qumran Congress, t. 1, STDJ 11.1 (1992), 295-305. 
Najbardziej wyrazistym przykładem ewolucji pism biblijnych w kierunku apokaliptyki jest Księga Izajasza. Jak powszechnie wiadomo, składa się ona z czterech bloków, powstałych w różnych okresach historii Izraela. Pierwsza część (tzw. Protoizajasz) to czas schyłku prosperity VIII wieku, bardzo skomplikowana sytuacja polityczna, zbliżające się zagrożenie utraty nawet względnej niepodległości, niedojrzałość władców i elit, zepsucie moralne oraz eklektyzm religijny. Wszystko to skłoniło proroka Izajasza do wygłaszania bardzo surowych pouczeń i napomnień - w jego ocenie wszystko było jeszcze możliwe. O jego optymizmie najlepiej świadczą nadzieje, jakie wiązał z synem króla Achaza - Ezechiaszem (por. Iz 7; 9), idea Reszty Izraela czy nawet liczne proroctwa przeciw narodom obcym (należy koniecznie pamiętać, że pisma te nie były adresowane do cudzoziemców, ale do Izraelitów, a klęska ich wrogów była dla nich wizją nader radosną). Księga Protoizajasza jest typowym przykładem proroctwa karcącego (mimo że nie brakuje w niej także elementów pocieszenia).

Wiele lat później, w czasie niewoli babilońskiej, powstała druga część tej Księgi, nazywana Deuteroizajaszem. Warunki radykalnie odmienne. Sytuacja była tak zła, że Deuteroizajasz wszelkimi możliwymi metodami stara się zaszczepić swoim rodakom nadzieję, która pozwoliłaby im przetrwać czas niewoli. Wybiera drogę obietnic - jego oracula pełne są wizji cudownego ocalenia, radości, obfitości wszystkiego, pokoju i sielankowego dobrobytu, a to wszystko praktycznie za nic, bez stawiania szczególnych warunków. W ten sposób stara się przekonać swoich rodaków do ufności w pomoc Bożą, do przekonania, że jest na co czekać i że wbrew pozorom nie wszystko jest jeszcze stracone. Jak pokazała późniejsza historia - w istocie swojego nauczania miał absolutną rację. Zauważmy - mimo że nakreślone w jego obietnicach obrazy kompletnie odbiegały od rzeczywistości pierwszych lat po zwycięstwie Persów nad Babilonem, nikt nie kwestionował prawdziwości jego proroctw! Mozolny powrót Izraelitów do zniszczonej ojczyzny w niczym nie przypominał deuteroizajaszowego radosnego pochodu wśród obfitości wody, zieleni i bogactw do utraconego raju, a jednak nie znajdziemy w Biblii ani śladu skierowanego wobec Deuteroizajasza zarzutu głoszenia nieprawdy.

Zderzenie nadziei i wyobrażeń związanych z odzyskaniem wytęsknionej wolności z szarą rzeczywistością okresu powrotów z niewoli było tak szokujące, że wywoływało nie tylko bolesne poczucie zawodu, ale i niemal bezsilną złość. Reakcją na taki stan rzeczy jest trzecia część Księgi - Tritoizajasz. Jest to przede wszystkim prorok głoszący, że Izraelici marnują daną im od Boga szansę, ale równocześnie zachęca do nadziei na cudowne odnowienie wszystkiego - począwszy od Izraela, poprzez narody pogań- 
skie, aż po cały kosmos. Nadzieja, jaką głosi, spełni się jednak dopiero w przyszłości, której nikt nie jest w stanie przewidzieć. To właśnie ta nie skonkretyzowana perspektywa zbawienia jest konstytutywnym elementem pism apokaliptycznych. Wizja kosmicznej interwencji JHWH oraz nieodgadniona perspektywa spełnienia się obietnic to właśnie pierwszy krok w stronę rodzącej się apokaliptyki.

Dalej drogą tą poszedł autor tzw. Apokalipsy Izajasza (24, 1 - 27, 13). Nie jest to jeszcze apokalipsa klasyczna, brak w niej większości typowych dla późniejszych apokalips elementów (takich jak chociażby aniołów, wizji sennych, wędrówek w zaświaty, walk pomiędzy armiami dobra i zła, reinterpretacji dawniejszych przepowiedni, wyznaczania konkretnych dat wydarzeń eschatologicznych i okresów je poprzedzających itp.), mimo to stylistyka tego fragmentu Księgi Izajasza upoważnia do zaliczenia tego dzieła do początkowej fazy kształtowania się nurtu apokaliptycznego. Obok charakterystycznego stylu wypowiedzi (terminologia kosmiczna, emfaza, elipsy itp.), pojawiają się w niej także najważniejsze motywy apokaliptyczne, a mianowicie: sąd nad całym światem, znaki na niebie, oczekiwanie gwałtownej i globalnej interwencji JHWH oraz czarno-białe podziały na dobrych i złych, zasługujących na niewyobrażalnie cudowne zbawienie i tych, których losem może być jedynie równie niewyobrażalne cierpienie.

Trudna do ustalenia jest data powstania Apokalipsy Izajasza. Wysuwane w tym wypadku propozycje sięgają od VI do II w. przed Chr. ${ }^{11}$ Ze względu na styl, tematykę, brak konkretnych odniesień do wydarzeń historycznych, powiązania z Dn, Jl, DtZa, etiopską Księgą Henocha i Pierwszą Księgą Henocha, można z dużą dozą prawdopodobieństwa powiedzieć, że fragment ten jest najmłodszą częścią Księgi Izajasza. Nie powstał więc wcześniej niż na przełomie V i IV wieku, a jeszcze bliższej datacji także nie można wykluczyć12.

W całej Księdze Izajasza widać jak na dłoni coraz bardziej oddalający się horyzont wizji prorockich. Nauczanie Protoizajasza skoncentrowane jest na problemach jemu aktualnych, a przyszłość ukazywana jest jako bezpośrednia konsekwencja teraźniejszości. Deuteroizajasz od tej teraźniejszości ucieka.

${ }^{11}$ Patrz: W. R. Mıllar, Isaiah 24-27 and the Origins of Apocalyptic, Missouri 1976, 1-22. Większość egzegetów opiera swoją datację o fragment 25, 2; 27, 10, identyfikując użyte tam wyrażenie „warowny ogród” jako Babilon, Samarię lub Jerozolimę i w zależności od tego odpowiednio definiując tło historyczne wyroczni. Metoda ta wzbudza jednak sporo zastrzeżeń, szczególnie z powodu braku pewności do integralności tego dzieła oraz bardzo niejasnych kryteriów takiej identyfikacji.

${ }^{12}$ Przy datowaniu tej części Iz należy także pamiętać, że nie jest to tekst integralny. Połączone w nim zostały fragmenty początkowo niezależne. Trudno więc osądzić, czy datacja powinna odnosić się do momentu powstania poszczególnych części składowych, czy też połączenia ich w całość. 
Jego wizje wydają się mówić: „nie zważajcie na to, co teraz - oto niedługo nadejdzie czas, że nasza sytuacja radykalnie się odmieni - będzie nieporównywalnie bardziej cudownie, niż teraz jest źle. A wszystko to stanie się już bardzo niedługo". Tritoizajasz każe swoim czytelnikom uzbroić się w cierpliwość, bo nikt nie zna dnia ani godziny, kiedy JHWH zadecyduje, że jest właściwa pora. Za to Jego przyjście nie będzie zwykłym ratunkiem z codziennych utrapień, ale prawdziwym Nowym Stworzeniem Nowego Świata, w którym nie będzie już miejsca na żadne zło. Wreszcie Apokalipsa Izajasza to jeszcze bardziej wyraźne przesunięcie perspektywy zbawienia na czas nieodgadniony. Wyraźnie widać przy tym regułę, że im mniej konkretny jest punkt odniesienia proroctw, tym bardziej cudownie przedstawiane jest wybawienie i tym przeraźliwsza jest wizja kary na wrogów i grzeszników.

Reguła ta widoczna jest także w odniesieniu do innych pism prorockich. Słabość impulsu spowodowanego brakiem bliskiej perspektywy spełnienia się nauczania prorockiego rekompensowano silniejszymi akcentami w samych wizjach. $\mathrm{Z}$ biegiem czasu stało się to po prostu niezwykle modnym środkiem wyrazu. Nawarstwienie grozy lub szczęścia w wizjach przemawiało do wyobraźni, a przez to wywoływało zamierzony efekt. Celem piśmiennictwa apokaliptycznego nie było przecież dostarczenie wiarygodnych opisów zdarzeń na świecie w jakiejś konkretnej przyszłości, ale wywołanie określonych reakcji czytelników czy słuchaczy. Bardzo trudna sytuacja (polityczna, społeczna, religijna i kultyczna) oraz brak w przewidywalnej przyszłości realnej perspektywy poprawy stanu rzeczy niejako zmusiły hagiografów do ucieczki do przodu, do przeniesienia nadziei na poprawę losu w odległą, ale za to jak nigdy dotąd cudowną przyszłość. 